\title{
Development of Engage, Research, and Present (ERP) Instructional Model to Promote HOTs and 21st Century Moral Values: A Fuzzy Delphy Method
}

\author{
S. Haryati ${ }^{1}$, S. Sukarno ${ }^{2}$, S. Siswanto ${ }^{3}$, Ahmad Muhlisin ${ }^{4}$, C.W. Anggraeni ${ }^{5}$, W.W.W Brata ${ }^{6}$ \\ \{ sriharyati@untidar.ac.id ${ }^{1}$, sukarno_edc@yahoo.co.id ${ }^{2}$, siswanto@untidar.ac.id ${ }^{3}$ \} \\ Faculty of Education and Teachers Training, Universitas Tidar, Magelang, Indonesia ${ }^{1,2,5}$ \\ Department of Natural Science Education, Universitas Tidar, Magelang, Indonesia ${ }^{3,4}$ \\ Department of Biology education, Universitas Negeri Medan, Medan, Indonesia ${ }^{6}$
}

\begin{abstract}
Higher order thinking skill (HOTs) and 21stcentury moral values are pivotal skills to be mastered by college students in todays' digitalized era. This study,therefore aims to develop am an instructional model called Engage, Research, and Present (ERP) model. This provides opportunities for college students owning HOTs and 21st moral values. The Fuzzy Delphi Method (FDM) was employed to determine consensus among a panel of several experts. They come from educational and psychological experts (i.e. researchers) and teachers who have experience at least 10 years. They should evaluate the ERP model encompassing 12 sub phases. Five sub-phases are included in Engage and Research, and two sub-phases encompassed in Present. Based on FDM approach, ERP instructional model provides several activities identified facilitating HOTs and 21st century moral values in science and social science learning.
\end{abstract}

Keywords: HOTs, 21st Century Moral Values, ERP model, Fuzzy Delphi Method

\section{Introduction}

One of the important activities in the teaching and learning process for college students is to acquire Higher Order Thinking Skill (HOTs). HOTs becomes one of the essential skills that should be included in the learning outcomes process in university [1]. HOTs therefore needs to be implemented in the teaching and learning process $[2,3]$ because students are able to face challenges and problems in their daily life when they master HOTs [4]. This argument is based on the fact that HOTs comprises scientific reasoning $[5,6]$ in which it is a crucial skill in solving daily issues. In addition, in the context of cognitive aspect, HOTs places the highest level of skill for critical and evaluative thinking, decision-making, problem-solving, and transfer to other situations $[2,7]$.

Despite emphasizing HOTs, the teaching and learning process should also emphasize character education. As we know, life becomes complex and it is easily affected the negative value as an impact of globalization era and technology development. In other word, the role of environment is crucial in shaping the character of the next generation. The development of information and technology then provides an effect on the change of environmental conditions. According to this situation, it is important to infuse positive character in the teaching and learning process [8, 9]. Many studies [10-12] revealed that learning process 
could embed positive character for students. Indeed, this also aims to avoid a negative value or character from a real situation.

Character encompasses the ways of thinking and taking action owned people for life, team work in family, society, and country [11-13]. Several typical characters that should be owned students, for instance, $21^{\text {st }}$ moral value [13]. They encompass: (1) showing the way of creative thinking and doing, (2) presenting the interest in lifelong education, (3) having the capability of learning to face problems, having the competence of being selective communicator, (5) having the courage to take risks, (6) having the capability of being hard work, (7) having the integrity of being honest and responsibility, and (8) showing the feeling of attention, tolerance, and flexible.

According to the previous argument of benefits of HOTs and $21^{\text {st }}$ moral values, there is a need to design an instructional model in college or university that facilitates students to obtain HOTs and character education needed to face problems in $21^{\text {st }}$ century. The type of instruction has to accommodate the aspects of HOTS and $21^{\text {st }}$ moral value both in natural and social science learning. This study, therefore, aims to explain an instructional model in which it trains HOTs and $21^{\text {st }}$ moral values for college students.

\section{Methods}

This study utilizes Fuzzy Delphy Method (FDM) that is by Kauffmann and Gupta [14]. This method is effective to acquire the agreement among several arguments in which these focuses on the group deal [15]. FDM is also effective in giving feasibility decisions of a learning phase [6]. In this present study, FDM is implemented as an analytic method in the deciding phase and sub-phase of an instructional model that is designed by an expert. The phase and sub phase arranged are based on the learning outcomes that encompass HOTs and $21^{\text {st }}$ moral values. This instructional model consists of three phases that comprise Engage, Research, and Present. Moreover, each phase has several sub phases. The phase of Engage and Research consists of five sub phases while the phase of Present has two sub phases (see Table 1).

Table 1. Description of Phase (P) and Sub Phases (SP) Developed-Instructional Model.

\begin{tabular}{clll}
\hline No & Phase (P) & & \multicolumn{1}{c}{ Sub Phases (SP) } \\
\hline 1 & Engage & 1 & Reading local wisdom based phenomena \\
& & 2 & Identifying the phenomena \\
& & Writing the research question \\
& & 4 & Reviewing related literature \\
& & 5 & Creating the map of investigating stage \\
\hline 2 & Research & 1 & Formulating hypothesis \\
& & 2 & Doing investigation \\
& 3 & Analyzing data and doing discussion \\
& 4 & Concluding the discussion \\
& 5 & Writing report \\
\hline 3 & Present & 1 & Making mind mapping of research activities \\
& & 2 & Presenting the research result by using mind \\
& & \\
\hline
\end{tabular}


There are ten experts in this study. The minimal number of experts who can be participants are ten [16]. Those experts consist of the experts of psychology and educators and teachers who have ten years of teaching experience. Those experts as participants of this study complete the questionnaire. FDM questionnaire developed consists of twelve items by combining Likert scale and fuzzy numbers. The number of questions is based on the number of sub-phase in the learning model designed. Then, the participants fill in the questionnaire and the researcher analyses the data. Data analysis is done in four stages.

The first step is dose by deciding the linguistic scale in which it uses Likert scale by adding three fuzzy numbers $\left(\mathrm{m}_{1}, \mathrm{~m}_{2}, \mathrm{~m}_{3}\right)$ that they have a scale of $0-1$. The linguistic scale can be seen in Table 2. Three fuzzy numbers are used to solve the problems for each participant so it has a triangulation fuzzy number. The second step is by counting the average score of fuzzy number $(\overline{F N})$ in each participant respond in the stage of ERP instructional model. The third step is by counting the threshold value (d) for deciding the agreement level among the participants by using the equation (1). The participants (experts) can be stated in the same agreement if the value is $d \leq 0,2$ and the percentage $(\%)$ is $\geq 75 \%$. If it is found in that condition, it can be stated that the stage status (S) is Acceptable (A), the rest is Unacceptable (UA). The fourth step is by giving the rank (R) to phase and sub phase of instructional model designed. This rank is applied as the priority consideration step that must be done in the phases. The rank is based on the value of the Defuzzification Process (DV), by using equation 2 .

$$
\begin{aligned}
d & =\sqrt{\frac{1}{3}\left[\left(M_{1}-m_{1}\right)^{2}+\left(M_{2}-m_{2}\right)^{2}+\left(M_{3}-m_{3}\right)^{2}\right.} \\
D V & =\frac{1}{3} *\left(m_{1}+m_{2}+m_{3}\right)
\end{aligned}
$$

Table 2. Linguistic Scale.

\begin{tabular}{cccc}
\hline \multirow{2}{*}{5 Point Linguistic Scales } & \multicolumn{3}{c}{ Fuzzy Number } \\
\cline { 2 - 4 } & $\mathrm{m}_{1}$ & $\mathrm{~m}_{2}$ & $\mathrm{~m}_{3}$ \\
\hline Strongly agree & 0,6 & 0,8 & 1 \\
Agree & 0,4 & 0,6 & 0,8 \\
Moderately agree & 0,2 & 0,4 & 0,6 \\
Not agree & 0 & 0,2 & 0,4 \\
Strongly not agree & 0 & 0 & 0,2 \\
\hline
\end{tabular}

\section{Results and Discussion}

The result of data analysis by considering the expert consensus for each sub-phase can be seen in Table 3, Table 4, and Table 5. Based on the tables, each sub-phase in the instructional of model phase can be agreed by experts and those are appropriate to be applied to facilitate HOTs and $21^{\text {st }}$ moral values. All sub phases have acceptability percentage of more than $95 \%$ and the values is $d \leq 0,2$. It means that all sub phases must be carried out and they can facilitate HOTs and $21^{\text {st }}$ moral values but they must consider different the priority order. The higher the sub phase rank, the more priority the sub-phases to be conducted. 
In Engage phase, the priority order is sub-phase number 2 as the first priority, sub-phase number 1 and 5 as the second priority, sub-phase number 3 gets the third priority, and subphase number 4 is in the fourth priority. In the Research phase, sub-phases number 2, 3, 5 obtain the first priority; while sub phases number 1 and 4 get the second priority. In present phase, sub phase number 2 is in the first priority and sub phase number 1 is in the second priority.

Instead of analyzing FDM data in sub-phases, FDM data analysis is also implemented in all phases (see Table 6). The analysis in all phases is used fuzzy number analysis in average, defuzzification process (DV) value, and phases rank. Based on the data analysis, research and presents phases are in the first rank, while the engage phase is in the second rank. It means that the phases of Research and Present are the priority phases to be implemented first before the Engage phase.

Table 3. Data analysis of experts responds in engage phase.

\begin{tabular}{|c|c|c|c|c|c|c|c|c|c|c|c|c|c|c|c|c|}
\hline \multirow{2}{*}{ SP } & \multirow{2}{*}{ FN } & \multicolumn{10}{|c|}{ Expert (FN) } & \multirow{2}{*}{$\overline{F N}$} & \multirow{2}{*}{$\mathrm{d} / \%$} & \multirow{2}{*}{$\mathrm{S}$} & \multirow{2}{*}{ DV } & \multirow{2}{*}{$\mathrm{R}$} \\
\hline & & 1 & 2 & 3 & 4 & 5 & 6 & 7 & 8 & 9 & 10 & & & & & \\
\hline \multirow{3}{*}{1} & $\mathrm{~m}_{1}$ & 0,6 & 0,6 & 0,6 & 0,6 & 0,4 & 0,4 & 0,4 & 0,6 & 0,6 & 0,6 & 0,54 & $0,06 /$ & A & 0,74 & 2 \\
\hline & $\mathrm{m}_{2}$ & 0,8 & 0,8 & 0,8 & 0,8 & 0,6 & 0,6 & 0,6 & 0,8 & 0,8 & 0,8 & 0,74 & 94 & & & \\
\hline & $\mathrm{m}_{3}$ & 1 & 1 & 1 & 1 & 0,8 & 0,8 & 0,8 & 1 & 1 & 1 & 0,94 & & & & \\
\hline \multirow{3}{*}{2} & $\mathrm{~m}_{1}$ & 0,6 & 0,6 & 0,6 & 0,6 & 0,4 & 0,6 & 0,6 & 0,6 & 0,6 & 0,4 & 0,56 & $0,04 /$ & $\mathrm{A}$ & 0,76 & 1 \\
\hline & $\mathrm{m}_{2}$ & 0,8 & 0,8 & 0,8 & 0,8 & 0,6 & 0,8 & 0,8 & 0,8 & 0,8 & 0,6 & 0,76 & 96 & & & \\
\hline & $\mathrm{m}_{3}$ & 1 & 1 & 1 & 1 & 0,8 & 1 & 1 & 1 & 1 & 0,8 & 0,96 & & & & \\
\hline \multirow{3}{*}{3} & $\mathrm{~m}_{1}$ & 0,6 & 0,6 & 0,4 & 0,4 & 0,4 & 0,6 & 0,4 & 0,6 & 0,6 & 0,6 & 0,52 & $0,08 /$ & A & 0,72 & 3 \\
\hline & $\mathrm{m}_{2}$ & 0,8 & 0,8 & 0,6 & 0,6 & 0,6 & 0,8 & 0,6 & 0,8 & 0,8 & 0,8 & 0,72 & 92 & & & \\
\hline & $\mathrm{m}_{3}$ & 1 & 1 & 0,8 & 0,8 & 0,8 & 1 & 0,8 & 1 & 1 & 1 & 0,92 & & & & \\
\hline \multirow{3}{*}{4} & $\mathrm{~m}_{1}$ & 0,6 & 0,6 & 0,4 & 0,6 & 0,2 & 0,6 & 0,4 & 0,6 & 0,6 & 0,4 & 0,50 & $0,10 /$ & $\mathrm{A}$ & 0,70 & 4 \\
\hline & $\mathrm{m}_{2}$ & 0,8 & 0,8 & 0,6 & 0,8 & 0,4 & 0,8 & 0,6 & 0,8 & 0,8 & 0,6 & 0,70 & 90 & & & \\
\hline & $\mathrm{m}_{3}$ & 1 & 1 & 0,8 & 1 & 0,6 & 1 & 0,8 & 1 & 1 & 0,8 & 0,90 & & & & \\
\hline \multirow{3}{*}{5} & $\mathrm{~m}_{1}$ & 0,6 & 0,6 & 0,6 & 0,6 & 0,4 & 0,6 & 0,4 & 0,6 & 0,6 & 0,4 & 0,54 & $0,06 /$ & A & 0,74 & 2 \\
\hline & $\mathrm{m}_{2}$ & 0,8 & 0,8 & 0,8 & 0,8 & 0,6 & 0,8 & 0,6 & 0,8 & 0,8 & 0,6 & 0,74 & 96 & & & \\
\hline & $\mathrm{m}_{3}$ & 1 & 1 & 1 & 1 & 0,8 & 1 & 0,8 & 1 & 1 & 0,8 & 0,94 & & & & \\
\hline
\end{tabular}

Table 4. Data analysis of experts responds in research phase.

\begin{tabular}{|c|c|c|c|c|c|c|c|c|c|c|c|c|c|c|c|c|}
\hline \multirow{2}{*}{ SP } & \multirow{2}{*}{$\mathrm{FN}$} & \multicolumn{10}{|c|}{ Expert (FN) } & \multirow{2}{*}{$\overline{F N}$} & \multirow{2}{*}{$\mathrm{d} / \%$} & \multirow{2}{*}{ A } & \multirow{2}{*}{$\mathrm{DV}$} & \multirow{2}{*}{$\mathrm{R}$} \\
\hline & & 1 & 2 & 3 & 4 & 5 & 6 & 7 & 8 & 9 & 10 & & & & & \\
\hline \multirow{3}{*}{1} & $\mathrm{~m}_{1}$ & 0,6 & 0,6 & 0,4 & 0,6 & 0,4 & 0,6 & 0,6 & 0,6 & 0,6 & 0,6 & 0,56 & $0,04 / 96$ & $\mathrm{~A}$ & 0,76 & 2 \\
\hline & $\mathrm{m}_{2}$ & 0,8 & 0,8 & 0,6 & 0,8 & 0,6 & 0,8 & 0,8 & 0,8 & 0,8 & 0,8 & 0,76 & & & & \\
\hline & $\mathrm{m}_{3}$ & 1 & 1 & 0,8 & 1 & 0,8 & 1 & 1 & 1 & 1 & 1 & 0,96 & & & & \\
\hline \multirow{3}{*}{2} & $\mathrm{~m}_{1}$ & 0,6 & 0,6 & 0,6 & 0,6 & 0,4 & 0,6 & 0,6 & 0,6 & 0,6 & 0,6 & 0,58 & $0,02 / 98$ & A & 0,78 & 1 \\
\hline & $\mathrm{m}_{2}$ & 0,8 & 0,8 & 0,8 & 0,8 & 0,6 & 0,8 & 0,8 & 0,8 & 0,8 & 0,8 & 0,78 & & & & \\
\hline & $\mathrm{m}_{3}$ & 1 & 1 & 1 & 1 & 0,8 & 1 & 1 & 1 & 1 & 1 & 0,98 & & & & \\
\hline \multirow{3}{*}{3} & $\mathrm{~m}_{1}$ & 0,6 & 0,6 & 0,6 & 0,6 & 0,4 & 0,6 & 0,6 & 0,6 & 0,6 & 0,6 & 0,58 & $0,02 / 98$ & A & 0,78 & 1 \\
\hline & $\mathrm{m}_{2}$ & 0,8 & 0,8 & 0,8 & 0,8 & 0,6 & 0,8 & 0,8 & 0,8 & 0,8 & 0,8 & 0,78 & & & & \\
\hline & $\mathrm{m}_{3}$ & 1 & 1 & 1 & 1 & 0,8 & 1 & 1 & 1 & 1 & 1 & 0,98 & & & & \\
\hline \multirow{3}{*}{4} & $\mathrm{~m}_{1}$ & 0,6 & 0,6 & 0,6 & 0,6 & 0,2 & 0,6 & 0,6 & 0,6 & 0,6 & 0,6 & 0,56 & $0,04 / 96$ & $\mathrm{~A}$ & 0,76 & 2 \\
\hline & $\mathrm{m}_{2}$ & 0,8 & 0,8 & 0,8 & 0,8 & 0,4 & 0,8 & 0,8 & 0,8 & 0,8 & 0,8 & 0,76 & & & & \\
\hline & $\mathrm{m}_{3}$ & 1 & 1 & 1 & 1 & 0,6 & 1 & 1 & 1 & 1 & 1 & 0,96 & & & & \\
\hline \multirow{3}{*}{5} & $\mathrm{~m}_{1}$ & 0,6 & 0,6 & 0,6 & 0,6 & 0,4 & 0,6 & 0,6 & 0,6 & 0,6 & 0,6 & 0,58 & $0,02 / 98$ & A & 0,78 & 1 \\
\hline & $\mathrm{m}_{2}$ & 0,8 & 0,8 & 0,8 & 0,8 & 0,6 & 0,8 & 0,8 & 0,8 & 0,8 & 0,8 & 0,78 & & & & \\
\hline & $\mathrm{m}_{3}$ & 1 & 1 & 1 & 1 & 0,8 & 1 & 1 & 1 & 1 & 1 & 0,98 & & & & \\
\hline
\end{tabular}


Table 5. Data analysis of experts responds in present phase.

\begin{tabular}{|c|c|c|c|c|c|c|c|c|c|c|c|c|c|c|c|c|}
\hline \multirow{2}{*}{ SP } & \multirow{2}{*}{$\mathrm{FN}$} & \multicolumn{10}{|c|}{ Expert (FN) } & \multirow{2}{*}{$\overline{F N}$} & \multirow{2}{*}{$\mathrm{d} / \%$} & \multirow{2}{*}{ A } & \multirow{2}{*}{ DV } & \multirow{2}{*}{$\mathrm{R}$} \\
\hline & & 1 & 2 & 3 & 4 & 5 & 6 & 7 & 8 & 9 & 10 & & & & & \\
\hline \multirow{3}{*}{1} & $\mathrm{~m}_{1}$ & 0,6 & 0,6 & 0,6 & 0,6 & 0,2 & 0,6 & 0,6 & 0,6 & 0,6 & 0,6 & 0,56 & $0,04 / 96$ & $\mathrm{~A}$ & 0,76 & 2 \\
\hline & $\mathrm{m}_{2}$ & 0,8 & 0,8 & 0,8 & 0,8 & 0,4 & 0,8 & 0,8 & 0,8 & 0,8 & 0,8 & 0,76 & & & & \\
\hline & $\mathrm{m}_{3}$ & 1 & 1 & 1 & 1 & 0,6 & 1 & 1 & 1 & 1 & 1 & 0,96 & & & & \\
\hline \multirow{3}{*}{2} & $\mathrm{~m}_{1}$ & 0,6 & 0,6 & 0,6 & 0,6 & 0,4 & 0,6 & 0,6 & 0,6 & 0,6 & 0,6 & 0,58 & $0,02 / 98$ & A & 0,78 & 1 \\
\hline & $\mathrm{m}_{2}$ & 0,8 & 0,8 & 0,8 & 0,8 & 0,6 & 0,8 & 0,8 & 0,8 & 0,8 & 0,8 & 0,78 & & & & \\
\hline & $\mathrm{m}_{3}$ & 1 & 1 & 1 & 1 & 0,8 & 1 & 1 & 1 & 1 & 1 & 0,98 & & & & \\
\hline
\end{tabular}

Table 6. Data of FDM for all phases.

\begin{tabular}{cccccc}
\hline \multirow{2}{*}{ Phase } & \multicolumn{3}{c}{ Fuzzy Number (FN) } & \multirow{2}{*}{ DV } & Rank \\
\cline { 2 - 4 } & $\mathrm{m}_{1}$ & $\mathrm{~m}_{2}$ & $\mathrm{~m}_{3}$ & & \\
\hline Engage & 0,53 & 0,73 & 0,93 & 0,73 & 2 \\
Research & 0,57 & 0,77 & 0,97 & 0,77 & 1 \\
Present & 0,57 & 0,77 & 0,97 & 0,77 & 1 \\
\hline
\end{tabular}

ERP instructional model is developed by using a learning concept based research. Several reasons are used as the basic rationale in using learning-based research: (1) Research becomes one of important aspects in higher education [17] and the learning trend currently [18]; (2) It integrated learning-based research activities that can improve students' learning outcomes [19] and learning based contextual problems [20],[21] because it facilitates students to construct the knowledge independently so as students understand and evaluate the concepts that have been learned [17],[22]; (3) Learning outcomes that encompasses cognitive, affective, and psychomotor can be achieved by students by applying research activities integrated in teaching and learning process [23]. It is therefore hoped that by using ERP instructional model that comprises research activities provides the students to acquire HOTs in science and social science learning.

In the Engage phase, there are activities to understand the local wisdom values so ERP model developed can be integrated with local wisdom. The idea of integrating Local Wisdom is seen by the advantages of local wisdom. First, local wisdom is very important to be integrated into the learning process [24]. Second, it is needed to introduce local wisdom to college students [25] so its values can be grasped by the students. Third, positive values of local wisdom can be interpreted by students [25],[26] to avoid the negative effect of the globalization era. Moreover, local wisdom relates to familiar event or phenomenon or object in each region and nation, particularly they are related to local culture [27]. Therefore, the combination of research activities and local wisdom values in science and social science learning can facilitate the college students to have 21 st century moral values.

According to benefits provided ERP instructional model, this provides two implications to science and social learning science in the classroom-as an alternative of the instructional model in strengthening research skills emphasizing collaborative learning strategy and new perspective in developing instructional model. First, in the context of goal of the learning process, ERP aims to strengthen the research capability of college students because it comprises several sub-phases accentuating research skill. When sub-phases of this model underpin some skills in research, the college students are engaged in all activities that lead 
how to conduct research scientifically. Second, this type of instructional model refers to a collaborative learning strategy in the classroom. This is a very pivotal aspect in supporting 21 st century skills needed by students. As we know, in the context of 21 st century learning, all students have to have collaborative skill. The skill of doing collaborative learning can widen other skills, for example, reasoning and argumentation skill. In addition, methodically, the use of FDM as a research method in developing the instructional model is relatively new in Indonesian educational research. Many Indonesian researchers focused on taking Research and Development method with taking a little expert to judge the framework of instructional model developed. In this method, at least ten experts value and provide feedback for an instructional model constructed so that this situation strengthens ERP model developed.

\section{Conclusions}

Based on the finding, it can be concluded that Engage, Research, and Present (ERP) instructional model facilitates Higher Order Thinking Skill (HOTs) and $21^{\text {st }}$ century moral values, both in science and social science learning. Each step in ERP model has sub-phase that has to be conducted. Engage phase has several staged: reading local wisdom based phenomena, identifying the phenomena, writing the research question, reviewing of related literature, and creating an identification map. The Research phase covers formulating hypothesis, doing investigation, analyzing data and doing discussion, concluding the research, and writing the report. Present phase reveals making mind mapping of research and presenting the research results by using mind mapping providing an opportunity to develop communication skill with others.

\section{References}

[1] Miller, S.: Developing higher order thinking skills. In Proceedings of The Australian Conference on Science and Mathematics Education (formerly UniServe Science Conference) (2012, August)

[2] Karim, F. A., Kayar, R., Cheng, T. J., \& Sopah, F. M.: Readiness in applying higher order thinking skills after attending courses. Human Sustainability Procedia(2018)

[3] Zohar, Anat, and Yehudit J. Dori: "Higher order thinking skills and low-achieving students: Are they mutually exclusive?." The journal of the learning sciences 12.2 pp. 145-181 (2003)

[4] Saido, G. M., Siraj, S., Nordin, A. B. B., \& Al_Amedy, O. S.: Higher order thinking skills among secondary school students in science learning. MOJES: Malaysian Online Journal of Educational Sciences, 3(3), pp.13-20 (2018)

[5] Vidergor, H. E.: Effectiveness of the multidimensional curriculum model in developing higherorder thinking skills in elementary and secondary students. The Curriculum Journal, 29(1), pp.95115(2018)

[6] G. A. M. Saido, S. Siraj, D. DeWitt \& O. S. Al-Amedy: Development of an instructional model for higher order thinking in science among secondary school students: a fuzzy Delphi approach, International Journal of Science Education, DOI: 10.1080/09500693.2018.1452307(2018)

[7] Bramwell-Lalor, S., \& Rainford, M.: The effects of using concept mapping for improvingadvanced level biology students' lower- and higher-order cognitive skills. International Journal of Science Education, 36(5), 839-864. doi:10.1080/09500693.2013.829255 (2014)

[8] Rahmi, M. M., \& Erlinda, R.: Teachers'role in building students'character through english language teaching classroom. In International Conference on Languages and Arts, pp. 320-327(2014, November) 
[9] Djailani, A. R.: Strategy Character Building of Students at Excellent Schools in the City Of Banda Aceh. IOSR Journal of Research \& Method in Education (IOSRJRME) e-ISSN: 2320-7388, p-ISSN: 2320-737X Volume, 1, pp. 49-59 (2013)

[10] Astin, H. S., \& Antonio, A. L.: Building character in college. About Campus, 5(5), pp. 3-7(2000)

[11] Komalasari, K.: The Living Values-Based Contextual Learning to Develop the Students' Character. Journal of Social Sciences, 8(2), 246 (2012)

[12] Rahmi, M. M., \& Erlinda, R.: Teachers'role in building students'character through english language teaching classroom. In International Conference on Languages and Arts, pp. 320-327 (2014, November)

[13] Parwati, N. N., Tegeh, I. M., \& Mariawan, I. M.: Integrating the Values of Local Wisdom into the Learning Model: Building Positive Student Character. In Educational 15 Technology to Improve Quality and Access on a Global Scale (pp. 297-307). Springer, Cham (2018)

[14] Kaufmann, A., \& Gupta, M. M.: Fuzzy mathematical models in engineering and management science. New York, NY: Elsevier Science Inc (1988)

[15] Baumfield, V. M., Conroy, J. C., Davis, R. A., \& Lundie, D. C.: The Delphi method: Gathering expert opinion in religious education. British Journal of Religious Education, 34(1), 5-19. doi:10.1080/01416200.2011.614740 (2012)

[16] Kuo, Y. F., \& Chen, P. C.: Constructing performance appraisal indicators for mobility of the service industries using Fuzzy Delphi Method. Expert Systems with Applications, 35(4), pp.1930 1939 (2008)

[17] Wannapiroon, P.: Development of research-based blended learning model to enhance graduate students' research competency and critical thinking skills. Procedia-Social and behavioral sciences, 136, pp.486-490 (2014)

[18] Junpeng, P., \& Tungkasamit, A.: The continuing professional development of the assessment through research-based learning in higher education of Thailand. Procedia-Social and Behavioral Sciences, 143, pp. 737-742 (2014)

[19] Srikoon, S., Bunterm, T., Samranjai, J., \& Wattanathorn, J.: Research synthesis of research-based learning for education in Thailand. Procedia-Social and Behavioral Sciences, 116, pp. 913-917 (2014) [20] Muhlisin, A., Susilo, H., Amin, M., \& Rohman, F. Improving Critical Thinking Skills of College Students Through RMS Model for Learning Basic Concepts in Science. Asia-Pacific Forum on Science Learning and Teaching, 17, (1), Article 12 (2016).

[21] Muhlisin, A. Reading, Mind Mapping, and Sharing (RMS): Innovation of New Learning Model on Science Lecture to Improve Understanding Concepts. Journal for the Education of Gifted Young Scientists, 7 (2), pp. 323-340 (2019).

[22] Muhlisin, A., Susilo, H., Amin, M., \& Rohman, F. The Effectiveness of RMS Learning Model in Improving Metacognitive Skills on Science Basic Concepts. Journal of Turkish Science Education, 15 (4), pp. 1-14 (2018).

[23] Sota, C., \& Peltzer, K.: The Effectiveness of Research Based Learning among Master degree Student for Health Promotion and Preventable Disease, Faculty of Public Health, Khon Kaen University, Thailand. Procedia-Social and Behavioral Sciences, 237, pp. 1359-1365 (2017)

[24] Selasih, N. N., \& Sudarsana, I. K.: Education Based on Ethnopedagogy in Maintaining and Conserving the Local Wisdom: A Literature Study. Jurnal Ilmiah Peuradeun, 6(2), pp.293-306 (2018) [25] Madlateh, A., \& Fawzi, A.: Integrating environmental local wisdom in learning through observation techniques. ISCE: Journal of Innovative Studies on Character and Education, 2(1), pp. 113 (2018)

[26] Relin, R., Rasna, I. W., \& Binawati, W. S.: Local Wisdom Values in Balinese Folktales That Are Relevant to Character Education for the First Grade at Primary School. Journal of Language Teaching and Research, 9(1), pp.155-163 (2018)

[27] Dewi, I. N., Poedjiastoeti, S., \& Prahani, B. K.: Elsii learning model based local wisdom to improve students' problem solving skills and scientific communication. International Journal of Education and Research, 5(1), pp.107-118 (2017) 